\title{
Lost in narration: rediscovering the Suomussalmi copper adze
}

\author{
Janne Ikäheimo \& Kerkko Nordqvist
}

Janne Ikäheimo*), Archaeology, Faculty of Humanities, Box 1000, 90014 Oulu University, Oulu, Finland. Phone: +358-50-350 3173. E-mail: janne.ikaheimo@oulu.fi

Kerkko Nordqvist, Archaeology, Faculty of Humanities, Box 1000, 90014 Oulu University, Oulu, Finland. Phone: +358-50-360 2913. E-mail: kerkko.nordqvist@gmail.com

*) corresponding author

Funding: This work has been supported by the University of Helsinki Grant \#490055 for the project Copper, material culture and the making of the world in Late Stone Age Finland and Russian Karelia (2010-2012); and by the Academy of Finland Grant \#269066 for the project The use of materials and the Neolithisation of North-Eastern Europe c. 6000-1000 BC (2013-2017). The authors express here their gratitude to these benefactors.

Abstract: The Suomussalmi copper adze is a native copper artefact discovered in 1980 on Kukkosaari Island (Suomussalmi, north-eastern Finland). Since then the artefact has been repetitiously used as an example when narrating the introduction of metal technology in prehistoric Finland, while its chronological position, function and significance have remained poorly studied. Here the object is reviewed both through the results of new metallographic analyses and by reexamining its position in the context of the early metal use in north-eastern Europe during the Neolithic and the Bronze Age. The results of metallographic analyses indicate that the adze was shaped by melting/casting followed by cold-hammering; both techniques are shown to have been used in the research area - Finland and north-west Russia - already during the Neolithic. While the provenance of the metal remains to be assigned, possible domestic, Karelian as well as Uralian sources are critically assayed. Instead of plain analyses regarding techno-typology and function, the Suomussalmi adze is here connected to the general enrichment of the (material) world during the Neolithic that took place multi-locally through the adoption new raw materials and the increased interest on their real or presumed properties.

Keywords: native copper, artefact, adze, Neolithic, metallography, prehistoric narrative(s)

Word count: 7065 (main text); 9951 (total) 


\section{Lost in narration: rediscovering the Suomussalmi copper adze}

\section{Introduction}

While written treatises on regional or national prehistories should, in theory, be based on the analysis of all available archaeological sources, more often than not they are built on carefully selected objects and archaeological sites used to illustrate particular aspects in the narratives. Sometimes, the importance of such objects regarding this purpose has been recognised since their discovery, but the narratives weaved around them might differ, even considerably, depending on the narrator.

Considering the great narrative about the prehistory of Finland, one such object is a unique metal find, the so-called Suomussalmi copper adze (Fig. 1); an artefact that has intrigued prehistorians since its discovery in the Kainuu region, north-eastern Finland (Fig. 2), some thirty-five years ago. While scientific analyses (Huurre 1982, p. 30, Hölttä and Rosenberg 1987, p. 407) have proven that the artefact in question consists of pure copper and can be thus classified as a native copper artefact, many other relevant aspects - its chronological position, function and significance - have remained poorly studied. Thus the adze has been re-interpreted depending on the need to adjust the great narrative (e.g. Edgren 1992, p. 70, Ylimaunu and Costopoulos 1998), and, furthermore, the arguments have largely been based on the partially poorly-founded explanations aired in the original publication introducing the artefact (Huurre 1982).

The ideas presented in previous studies form a background against which the present paper will continue the contextualisation of the Suomussalmi copper adze. This discussion has several aims. Firstly, the present authors agree with previous research that the Suomussalmi copper adze is a particular and extraordinary find and, for this reason alone, merits - for the first time - a detailed description in English. The paper presents also the results of new metallographic analyses made on the object. Regarding its context, less attention will be paid on the specific find location, while adze's position in the wider context, that is, the early metal use in north-eastern Europe during the Neolithic and the Bronze Age will be assessed more thoroughly ${ }^{1}$. Finally, an attempt will be made to analyse the factors behind the early metal use and to present a re-assessment on the 'function' and 'meaning' of the Suomussalmi copper adze from a new perspective.

\section{The artefact}


As the story goes, the Suomussalmi copper adze (KM 20850) was found by a schoolgirl named Tita Vester on the Kukkosaari Island in June 1980 (Figs. 3-4). His father, Lippo Vester, the teacher of the local elementary school had found potsherds and other Neolithic materials on the island during an exceptionally dry summer in 1978 (Huurre 1982, p. 17). By November 1978 these finds had found their way to the offices of the National Board of Antiquities of Finland (henceforth NBA) located in Helsinki. In the following year, archaeological excavations were carried out on the island by MA Heikki Matiskainen (Matiskainen 1979), but the adze surfaced only a year later nearby the southernmost excavation area, 'on a sandy shore between the rocks'.

The copper object was soon transported to the NBA offices, and redeemed to its collections with a generous sum of 1500 Finnish marks. Translated to today's (2015) purchase power the money equals roughly 737 euros or approximately 825 US dollars. As the real value of copper metal was in August 1980 only 13.85 Finnish marks (i.e. c. 6.6 euros) per kilogram, the compensation exceeded c. 360 times the raw material value of the adze. From the previous ratio it is also quite easy to get a rough estimation of one important property of the artefact: it weighs no less than 309 grams. External dimensions of the adze have usually been quite accurately reported as $82 \times 28-45 \times 18 \mathrm{~mm}$ - the variation in width is explained by specimen's trapezoid shape as the blade quite naturally exceeds the stem in breadth (Fig. 1) ${ }^{2}$.

In addition to the trapezoid shape, the specimen is characterized by relatively flat, just slightly convex backside, while the frontside develops into a substantially wide convex gouge. The angle between the two sides is $c .25^{\circ}$ on the blade, while the edge is $c .3 \mathrm{~mm}$ thick and therefore blunt. The stem of the adze is uneven, but rectangular in section. The surface of the object is heavily corroded and displays various green hues of copper chloride and copper carbonate but the right flank, where patches of reddish brown copper oxide formation can be seen.

The Kukkosaari Island is a narrow north-east-south-west -oriented esker in the Kiantajärvi Lake (Fig. 4), which has been heavily regulated after the construction of a dam and a hydroelectric power plant in the 1960s. After the initial rise of 2-3 m, the fluctuating water level resulting from the ongoing regulation has eroded not only the Kukkosaari site, but also the other sites located next to the shoreline in the Kiantajärvi Lake area. In fact, archaeological fieldworks executed due to the dam construction and the consequent water regulation in Suomussalmi have revealed an exceptionally dense cluster of Bronze Age sites even in the scale of northern Europe (see e.g. Huurre 1982, 1986a, Lavento 2001, pp. 119-132). The regulation of water level and the erosion of 
shoreline also explain why the copper adze was found in an archaeological site without a proper context.

The chronology of the Kukkosaari site, based on the artefacts and pottery typology, extends from the Late Mesolithic to the Early Iron Age (Huurre 1982, pp. 17-18) and thus leaves ample margins for the date of the artefact. This characteristic of the site was also observed in the archaeological test excavations carried out on the island in 1999-2000 (Hyttinen et al. 2000, 2001). Therefore, the few attempts to date the adze have been mainly based on its raw material as well as on its shape and presumed comparanda. The dating usually put forward in publications has been founded on an approximate dating given by Huurre (1982, p. 21, 1986a, p. 88, 1986b, p. 53), who placed the adze to around 2000 uncalibrated BC or more widely to the 3rd millennium uncalibrated BC, which equals calibrated c. 3800-2500 cal. BC.

\section{From here, there or everywhere - the results of elemental analyses}

The anomalous nature of the Suomussalmi copper adze is further underlined by the number of elemental analyses carried out on samples taken from this artefact. Before the recent project focusing on Neolithic copper finds from Finland and north-western Russia, the adze had been analysed for its elemental composition already twice. The first analysis was carried out at the Outotec Research Center in Pori during the early 1980s with atomic emission spectrometry using Hilger arc emission spectroscope (for the identification of the method, see Ikäheimo 2011). The results were included in an article discussing the Early Metal Age in the Suomussalmi area (Huurre 1982), in which the interpretation of this analytic data is quite shallow - it practically forms a backdrop for the speculation about the most likely provenience for the object and its raw material. Also the results were reported in rather ambiguous way; the total amount of impurities was stated to be less than 0.3 per mil (Huurre 1992, p. 40), while the figures given in the respective table reproduced here in Table 1 - suggests that elements falling below the detection limit have also been included in the results.

The Suomussalmi copper adze was subjected to compositional analysis for the second time, when a sample from it was included, together with samples pertaining to six bronze celts, in a program exploring the potential of instrumental neutron activation analysis (INAA) in the research of archaeological metals (Hölttä and Rosenberg 1987). The results were given out as a table of $\mu \mathrm{g} / \mathrm{g}$ - 
values, but the respective comments focused exclusively on the applicability of the method rather than on archaeological interpretation of the results. Nevertheless, the analysis showed that while the presence of altogether 15 elements was detected, the combined amount of impurities was less than $0.1 \%$ thus qualifying the metal as native copper.

The third elemental analysis was a by-product of the aforementioned project, as samples taken from various native copper objects were pre-screened with an electron microprobe (EPMA) to get first-hand information on the microstructure and possible impurities present in the metal. In case of the Suomussalmi copper adze, the main aim was to visually inspect whether the silver detected in previous INAA-analysis was homogeneously dispersed in copper or present as visually recognisable impurities. Because silver occurs as minute $(<10 \mu \mathrm{m})$ grains in native copper associated with c. 2.06 Ga old volcanic formations of Imandra/Varzuga Greenstone Belt in the Kola Peninsula (Chernyavsky et al. 2010, p. 107, Melezhik 2012), the possibility that the metal of the Suomussalmi copper adze would be native copper pertaining to that region was thus explored. The result of this particular investigation was negative as no silver grains were observed, while the presence of silver - the most prominent impurity in the INAA-analysis - was also detected with the EPMA.

When the results of the three different analyses are evaluated together, they do not add much to our knowledge on the origin of metal in the Suomussalmi copper adze. The hypothesized use of untreated native copper from the Kola-region, based on the assumed presence of distinct silver impurities, may be excluded, while other directions - the Urals and the Lake Onega region in particular - can still be considered as equally potential sources due the lack of comparative data and the ambiguous nature of the copper deposits (Kuleff and Pernicka 1995, Mauk and Hancock 1998). In addition, the possibility that the raw material would have been derived from domestic sources, as first suggested by Huurre (1982, p. 21, 1986a, p. 87, see also Ikäheimo 2014), is worth reconsidering in the light of recent advances in geological ore exploitation and new archaeological finds of native copper in Finland. This topic will receive more profound treatment later on in this article.

\section{Manufacturing technique - the results of metallographic analyses}

The principal manufacturing technique -related statement - originally presented by Huurre (1982, p. 20) - regarding the Suomussalmi copper adze is that the artefact has been formed by (cold) 
hammering together the opposite edges of a single oval-shaped metal plate. The production sequence, even though on smaller scale, has been described and illustrated in connection with the fabrication of tanged arrowheads in sub-arctic North America (e.g. Franklin et al. 1981, p. 30, Fig. 12). The manufacturing technique has usually been taken as a proof of the object's considerable age (e.g. Huurre 1982, p. 20), while other scholars have insisted that the artefact belongs to the era when casting of molten metal was also known (e.g. Salo 1984, p. 106). No evidence supporting the latter claim, however, has been put forward to date.

At the outset, it would seem reasonable to exclude casting as a production method, because in the majority of cases the use of it would show up in the chemical composition of the object as increased presence of impurities (Wayman 1985b, pp. 75-76, Wayman and Duke 1999), and the metal of the Suomussalmi adze has been proven to be native copper with three independent analyses. By excluding momentarily the use of casting, two possible lines of investigation open up. Firstly, the adze could have been shaped from a single nugget or a chunk of native copper. Secondly, it could result from joining several pieces of native copper together mechanically. Both of these options will be evaluated next to some detail.

At first, the idea about a single chunk as a source for native copper needed in the making of the Suomussalmi adze seems, in a way, the most plausible of the three competing explanations. The most important precondition is that weathered chunks of suitable size were available in the first place - the properties of native copper, together with rather primitive mining tools available during the Neolithic, inhibited the extraction of raw material directly from the exposed vein containing native copper and the reduction of larger native copper chunks into small manageable pieces was equally problematic (Tylecote 1987, p. 90, Martin 1999, pp. 87-89). Thus, following the traditional view, the maximum size of the native copper object was governed by the size of raw material chunk available (e.g. Franklin et al. 1981, p. 34, Martin 1999, pp. 87-89).

If this was the case, the Suomussalmi copper adze would be the result of a lucky coincidence. It is by far the heaviest native copper artefact found in north-eastern Europe; it weighs nearly twenty times more than the Kierikki copper knife $(16.2 \mathrm{~g})$, the second heaviest native copper specimen from Finland (see Ikäheimo and Pääkkönen 2009), and approximately five times more than all the other Finnish Neolithic copper finds combined together. Comparable artefacts with respect to the amount of metal utilised are neither known from north-western Russia, although the total amount of copper discovered in Karelia exceeds the weight of the Suomussalmi copper adze multifold. 
At the present, some 30 Stone Age sites with copper finds are known in north-eastern Europe (Fig. 1) with the number of individual (published) finds barely exceeding 200 pieces. The majority of finds are small unworked copper nuggets or indeterminate pieces of hammered metal, and 'actual' artefacts are few and sporadic (for an overview, see Nordqvist et al. 2012, Nordqvist and Herva 2013). The distribution of finds is heavily concentrated in the western and northern Lake Onega region, where deposits of native copper and apparently also larger chunks of native copper were available. Archaeological excavations in the area have yielded pieces or nuggets of copper weighing up to 200 g (e.g. Gurina 1961, p. 290, Zhuravlev 1991, p. 23), and during a recent visit to Russia the authors were shown a substantially large nugget, at least $80 \times 60 \times 40 \mathrm{~cm}$ in size, originating from Beregovoye outcrop at the archaeological exhibition of the Karelian Scientific Centre in Petrozavodsk. The more important question is whether such pieces were commonly available due to weathering of copper outcrops during the Stone Age, and if such sources were completely exhausted at some point in prehistory (for corresponding situation in the US, see Maddin et al. 1980, p. 213).

The third and yet unexplored option is that the Suomussalmi adze was put together from numerous separate pieces of native copper through the painstaking processes of folding and annealing (see e.g. Martin 1999, pp. 128-129). The question whether the application of such technique would have been even theoretically possible is an issue that has been reviewed ambiguously in respective literature. On one hand, some publications state explicitly that pieces of native copper cannot be joined together through cold hammering or annealing (Coghlan 1975, p. 120), while, on the other hand, larger copper objects have reportedly been put together from several nuggets by hammering them first into thin sheets which were then folded and annealed together (Franklin et al. 1981, pp. 34-35). Now the question goes, which of these three methods was most likely used in the case of the Suomussalmi copper adze.

To resolve the question regarding the manufacturing technique, a permission to take a metal sample from the Suomussalmi adze was requested from the NBA. After the permission was granted, a small amount of metal was removed from the stem of the adze by an artefact conservator working for the NBA. Thereafter, the sample was sent to the thin-section laboratory of the Geological Survey of Finland located in Kuopio, where it was cast into epoxy resin and polished for microscopic inspection. The sample was examined at the Materials Engineering Laboratory of the Department of Mechanical Engineering, Oulu University with Nikon Eclipse MA100 
metallographic microscope mounted with Nikon Digital Sight-2Mv High Speed Color Camera Head. The examination took place both before and after etching with a generic copper etchant, using $5 x$ to 50x magnification range both with plain and polarised light.

The microscopy of a non-etched sample revealed the sparse presence of well-formed light blue cubic crystals and rows of similarly coloured small blebs, the latter of which seem to occur in a 45 degree angle when compared to crystal borders (Fig. 5a). These features, which are also faintly recognisable in photographs taken with the electron microprobe, can be identified as copper oxide named cuprite $\left(\mathrm{Cu}_{2} \mathrm{O}\right)$. While cuprite is a common end product of copper corrosion, the small blebs are far too regularly distributed through the polished surface in order to be interpreted as the first stage of advancing metal corrosion.

Instead, these blebs reveal the primary manufacturing technique of the Suomussalmi copper adze; the object has been casted from native copper (see e.g. Coghlan 1962, p. 64, Tylecote 1987, p. 93, Wilson et al. 1997, p. 59, Wayman and Duke 1999, p. 59). Thus, the knowledge of advanced pyrotechnology has been an important prerequisite for its production, as the melting point of copper $\left(1084.62{ }^{\circ} \mathrm{C}\right)$ had to be reached. The presence of silver as the main trace element can also be interpreted as corroborating evidence for the use of this technique, as it is one of the elements homogenised by casting (Wayman and Duke 1999, p. 62). At the same time, the homogeneous distribution of silver re-opens the possibility that the native copper used in casting or at least some of it could pertain to the deposits located in the Kola Peninsula.

While the significance of the manufacturing technique for the interpretation of the object will be discussed more thoroughly later on in this paper, it must be pointed out here that copper melting and possibly even casting were not unknown technologies in Karelia among the groups producing asbestos- and organic-tempered wares during the later 4th and early 3rd millennium BC (Zhuravlev et al. 1991, Zhulnikov 1999, p. 66, also Nordqvist and Herva 2013, p. 418). Another feature of substantial importance is the pureness of the metal in the adze, which is an indication of the considerable attention paid to the process of manufacturing, even though experiments have shown that melted native copper is chemically relatively stable (Wayman and Duke 1999, p. 62).

More information about the manufacturing process was gained through the examination of the etched sample (Fig. 5b), which showed the considerable heterogeneity of copper crystals, ranging from c. 130 to $300 \mu \mathrm{m}$ in size. The other apparent indication of extensive cold working is the plentiful presence of twinned crystals, some of which show curved twin boundary. The use of cold 
hammering is further corroborated by the presence of microscopic strain marks within the crystal structure. As the sample was taken from the stem of the adze, the microstructure is a reflection of procedures that preceded the folding of the flanks that was a necessary stage in shaping of the final product. Slightly different microstructure would probably have been observed, had the sample been taken from the blade end of the adze that was in all likelihood worked further than the stem (see e.g. Schroeder and Ruhl 1968, p. 165 Fig. 6).

In addition to metallographic analysis, the preceding argument applies equally to the Vickers test of microhardness that was also performed on the sample. The test took place at the Laboratory of Material Technology, Oulu University, using an M-type mechanical microhardness detector NTM001 manufactured by Shimadzu Seisakusho Ltd. The time used for applying a force to sample surface was 15 seconds, while the load was set to $15 \mathrm{~g}$. The analysis was performed thrice on the specimen, each time on a different spot. The points for analysis were chosen from areas free of visible scratches or other structural defects on the metal surface. The final result, HV 98.6 was averaged from the three separate measurements. The result is slightly above the average Vickers hardness of c. 20 tested samples from geological specimens as well as native copper nuggets, preforms and artefacts found in archaeological contexts from Finland and Russian Karelia (HV 60.2129).

When compared to values reported for pure copper artefacts representing different stages of annealing/forging, the hardness of the Suomussalmi adze falls in the middle of the spectrum, as annealed/untreated native copper should yield values around HV 55-60 or even less and forged, especially cold forged pieces, can be hammered up to the hardness of HV 130-140 before the metal is turned overly brittle (Coghlan 1975, p. 77, Tylecote 1987, p. 90, Grigoriev 2015, p. 84). This implies that the whole artefact preform was forged to some extent before the flanges were folded over to shape the basic form of the adze. Had the sample been taken from the blade end of the adze, which was not possible without severely altering the integrity of the object, somewhat higher Vickers hardness reading would have been the result. Anyhow, the current result is enough to show the intentionality behind the forming process; the object was designed to resemble an adze, while the adze itself might have had a practical, symbolic or other function.

\section{Earlier interpretations revisited}

Previous research has perceived the Suomussalmi copper adze as a metal artefact found in an otherwise completely Stone Age context and/or a peculiar specimen wound up to Finland through 
eastern connections, possibly indirectly reflecting distant ideas of a new raw material but still totally detached from the actual (and later) metallurgy of north-eastern Europe (Huurre 1982, p. 21, 1986b, pp. 51-52, Salo 1984, p. 106, Edgren 1992, p. 70, Lavento 2001, p. 183). The artefact is, indeed, unique as no direct parallels in metal can be pointed out for the Suomussalmi adze from Finland or the regions nearby. The only metal objects resembling it even remotely (Fig. 6) are a cast preform of a native copper adze from Varris, northern Sweden (Huggert 1996) and another cast native copper adze from Zalavruga IV (Zhuravlev et al. 1981, Zhuravlev 1991, pp. 198-200), both of which differ considerably in their shape and dimensions from the Suomussalmi adze. In addition, despite their uncertain find contexts, both examples have been suggested to be of somewhat younger date than the Suomussalmi adze.

Due to the lack of direct parallels some scholars have underlined the importance of the existence of similar objects in stone (e.g. Huurre 1982, p. 20), but the actual presented comparanda is limited to one example in Russian material published by A.M. Tallgren no later than in 1911 (Tallgren 1911, pp. 123-124). The artefact in question doesn't resemble much the Suomussalmi adze, while general references to East or Russian Karelian stone adzes have also been made (Huurre 1999). The idea behind these comparisons is that the familiar artefact form in stone was transferred into new raw material, as the makers were not yet able to realise the potential of the novel material itself (Huurre 1982, p. 20, 1983, p. 245, 1986a, p. 87, 1998, p. 353) - in other words, the inexperienced makers treated copper as just another type of stone (see Zhuravlev 1991, p. 144 for a similar opinion on early copper working in the Lake Onega region). Likewise, parallels in stone have also been drawn for other 'spectacular' early copper artefacts, including the adze from Varris (Huggert 1996, p. 74), the ring from Polvijärvi Suovaara (Sarvas 1969, p. 33), and the knife from Kierikki Kuuselankangas (Ikäheimo and Pääkkönen 2009, p. 170) and Karlebotnbakken (Schanche 1989, p. $64)^{3}$. The existence of potential parallels in stone and the degree of their similarity may, however, be somewhat irrelevant, as the significance and function of the adze may well be found in the specific properties of the very specimen or its raw material, as will be pointed out below.

The position and dating of early copper artefacts in the wider treatises of prehistory have been largely dependent on the ideas the particular archaeologists and/or contemporary master narratives have had on the appearance of metal. Stone Age copper finds have been known in the Karelian Republic since the late 1930s (Gurina 1951, 1961, Kosmenko and Kochkurkina 1996, Zhuravlev 1991, Zhulnikov 1999) and - following the research tradition of more southern Russia - 
an Eneolithic period has been defined for the area (see Kosmenko and Kochkurkina 1996, pp. 149152, Zhulnikov 1999, pp. 64-67, see also Nordqvist 2013, p. 189). Although the existence of Karelian coppers was known to Finnish scholars, the finds made in Finland were until fairly recently considered anomalous. The oldest copper artefact in Finland is the Polvijärvi copper ring found in the eastern part of the country in 1960 (Björkman 1961, Sarvas 1969, Taavitsainen 1982). This find, together with the Suomussalmi adze, and often also with the Jettböle metal sheets found on the Åland Islands ${ }^{4}$, have been showcased as the earliest metal finds in Finland (e.g. Huurre 1983, pp. 243-244, 1986, p. 53, Salo 1984, pp. 106-107, Edgren 1992, p. 70). Initially the Stone Age dating of these objects was questioned (e.g. Meinander 1962, see also Taavitsainen 1982, pp. 41-43) and in some cases they were connected to chronologically later Seima-Turbino phenomenon of the Early Bronze Age (e.g. Salo 1984, p. 106, also Huurre 1979, p. 94). Even after their Stone Age dating was accepted, these artefacts were seen as curiosities and it was strongly emphasised that they did not herald 'proper metal age' or covey any deeper knowledge of metal (e.g. Huurre 1983, p. 245, Edgren 1992, p. 70). However, new finds and studies have clarified that while not common; copper was neither a complete curiosity in Finland during the Neolithic (see e.g. Nordqvist et al. 2012, Nordqvist and Herva 2013).

Still, until recently the ambiguous nature of the Suomussalmi copper adze and the Polvijärvi copper ring was further underlined by their context in the great narrative told about the Finnish prehistory in the National Museum of Finland. The two objects were positioned next to one another in a display case devoted to the material culture of the Bronze Age in inland Finland. While the chronological context of the Polvijärvi ring was hereby misinterpreted by two millennia, the evaluation of the cultural context was equally puzzling. The title of the plaque introducing the finds announced that 'Inland is keeping up with the progress', suggesting explicitly that the actual progress was made elsewhere. The main body text, however, made quite clear that the first steps of proper metallurgy were taken elsewhere than among the Bronze Age societies inhabiting the west coast of Finland. As the permanent prehistory exhibition of the National Museum in currently under renovation, it remains to be seen in what kind of context - both physical and interpretative these two objects will be displayed next or whether they will be displayed at all.

Another central issue in previous research has been the determination of origins of the Suomussalmi adze. Based on the above-mentioned analyses and the observed elemental composition, it has usually been connected to the Urals region (Huurre 1982, p. 21, 1983, p. 245, 
1998, pp. 353-354). However, it is worth noticing that there are significant problems in the analyses themselves, in their comparability as well as in the availability of reference material - therefore the discussion about the provenience has usually remained on general-level sketching based more on the preconceptions of researchers than the actual data (see Huggert 1996, p. 79, Ikäheimo and Pääkkönen 2009, p. 162). It suffices to say here that among Finnish scholars the Urals has traditionally been considered as the more plausible origin for the Stone Age copper found in Finland and, to some extent, even for the copper found in Karelia (Taavitsainen 1982, p. 48, Huurre 1982, p. 21, 1983, p. 245, 1998, pp. 353-354, Edgren 1992, p. 70, but see e.g. Zhuravlev 1991, p. 142, Zhulnikov 1999, p. 67 for Russian views). Accordingly, Karelian sources of native copper have been overlooked in Finland until recently (Lavento 2001, p. 120, 2003, p. 248, Nordqvist et al. 2012, pp. 15-16).

One possibility that has been mentioned only briefly (Huurre 1982, p. 21), is the utilisation of local raw material. While metallic copper in Finland is mostly bound to sulfide copper ores, the presence of native copper has been documented in some thirty deposits (Laitakari 1967, Saltikoff 1997, Hytönen 1999, Västi 2010). In few cases copper is present only as microscopic grains, while the biggest geologic specimens that have ended up into geological museums are just some centimetres in size (Hytönen 1999, p. 184). Such amount of material would have been sufficient for the production of small items like beads or for the use of native copper nuggets per se (see below).

Another interesting question is to which extent was so-called float copper - native copper displaced by a glacier during the last Ice Age and therefore found in glacial till or glacio-fluvial sediments utilised during the Neolithic in north-eastern Europe? While its importance has been recognised in North America for long (e.g. Wayman 1985a, p. 68, Rapp 2009, pp. 154-157, Clark and Martin 2005, p. 111), the situation in Finland is, at the moment, based rather on vague leads than on solid evidence. One potential source for float copper could be, for example, the Eno-Kontiolahti area located between Lake Höytiäinen and Lake Pielinen in eastern Finland. This is the area, where altogether 15 small copper mines were established during the early 19th century (e.g. Vesajoki 2000, Kinnunen 2010), and the presence of native copper near the ground surface has been verified with geological surveying (Laitakari 1967, Hytönen 1999, p. 185). This idea is partially corroborated by the discovery of several native copper pieces from the Neolithic dwelling site of Rääkkylä Vihi 1 located some 75 kilometres south-south-east of the area, while recent archaeological excavations on other contemporary sites closer to the copper sources are practically non-existent. In all, while 
the evidence accumulated so far does not allow bold statements regarding the 'domestic' origin of native copper used in the Neolithic, this possibility should neither be ignored nor be totally ruled out (Ikäheimo 2014, pp. 21-22).

\section{Suomussalmi copper adze and prehistoric narratives}

As mentioned above, the Suomussalmi adze is a unique specimen with no direct parallels. If it is compared with the Stone Age copper finds, it differs from these before anything due to its size and manufacturing process. On the other hand, when the Suomussalmi adze is compared with the Bronze Age artefacts, large differences are also obvious, the most important of these being the difference in raw material. No native copper artefacts are known from Bronze Age contexts in the research area, although this may also be due to the fact that such specimens are customarily labelled as pre-Bronze Age. All in all, the question of continuity and discontinuity between the Late Neolithic and the Early Bronze Age is a problematic one. It is not totally clear how much - if at all these traditions overlap, but thus far no clear relationship has been observed between the Stone Age and Bronze Age metal use. According to the commonly held view, the Stone Age metal production and use of local raw material sources cease and give way to the more advanced, or 'proper', metallurgy of the Bronze Age, which was based on new imported artefacts, raw material and skills (e.g. Salo 1981, p. 413, Huurre 1982, pp. 21, 29, 1986b, pp. 52-56, Zhuravlev et al. 1991, Chernykh 1992, pp. 189, 214, Kosmenko and Kochkurkina 1996, pp. 151, 185, 208-209). On the other hand, a couple of metal finds from the so-called 'lapp cairns', the initial use of which in inland is currently drawn already to the Late Neolithic (Taavitsainen 2003, Saipio 2011, also Okkonen 2003) were noted to be bronzes in preliminary pXRF analysis (Ikäheimo 2014, p. 16, Table 3); similar results were obtained for the numerous but contextless metal finds from Kainuu and Suomussalmi area (see Huurre 1982, Lavento 2001, pp. 119-126, Ikäheimo 2014, p. 16, Table 3).

Although the adze would be more at home with the Bronze Age artefacts in respect of its size, there are more features that point towards its Stone Age dating. Accepting the Stone Age dating for the Suomussalmi adze places it at first only roughly to the era of Stone Age copper use, i.e. between $c$. 4000 and 2000 BC. If the assumed analogies with East Karelian adzes are accepted as a guideline, the dating can be tuned towards the later 4th and early 3rd millennium BC (see Tarasov 2004, 2008). This period of time also seems to be the apex of Stone Age copper use in the north (Nordqvist et al. 2012, pp. 6-9, Nordqvist and Herva 2013, pp. 416-418), but still either later 3rd or 
even early 2nd millennium BC dating cannot be ruled out. The cultural context of the adze is also somewhat unclear, but is illuminated by the utilized technology. The oldest copper finds in northeastern Europe originate from the contexts of Rhomb-Pit and Typical Comb Wares of the earlier 4th millennium BC, and are only cold hammered, whereas finds from the later 4th and 3rd millennium BC contain also specimens manufactured with more advanced techniques, including casting (see Zhuravlev 1991, p. 198, Zhuravlev et al. 1991, Zhulnikov 1999, p. 66). Thus, the adze could belong to this time period, and to the cultural context of asbestos- and organic tempered wares, also present at the adjacent settlement site ${ }^{5}$.

Although the exact dating of the Suomussalmi adze will most likely never be resolved, it is important to note that certain properties of the artefact itself can further be used to strengthen its connection to the Neolithic. Recent research has pointed out that the Mesolithic-Neolithic transition was not just about a change in the subsistence base or the adoption of ceramic technology - it was equally or even more about the transformation of societies and mentalities (see e.g. Watkins 2013, Herva et al. 2014, Thomas 2015). An important feature reflecting the altering relationship between the humans and the environment was the enrichment of the (material) world through the adoption of new raw materials and the increased interest on the real or presumed properties of these materials and on the mineral world in general (e.g. Boivin 2004, Davies and Robb 2004, Gaydarska and Chapman 2008, Johnston 2008, Herva et al. 2012, 2014 with cited literature). The attentiveness to the (sensory) properties of new places and materials (see Tilley 2007) and the novel ways of working and interacting with them thus expanded the lived world and revealed new dimensions of the reality to the Stone Age people. The adoption of copper, understood here as one of the new mineral materials with specific properties, fits in this development perfectly.

The reasons and meanings behind the Stone Age copper use in all of north-eastern Europe has been distorted by views concentrating only on trade and status -related issues as well as on technotypological analyses of artefacts (see e.g. Zhuravlev et al. 1991, Zhulnikov 1999, Núñez and Okkonen 2006, Zvelebil 2006). This pronouncedly western and modern view emphasizing the 'natural' and 'inherent' lure and 'superiority' of metal and the importance of its technological properties in its initial spread and adoption has resulted in views where metal is assigned 'cultural meaning' only after it was used for the production of 'rationally functional' artefacts (see e.g. Salo 1981, pp. 26, 33, Huurre 1998, p. 351, cf. Ottaway and Roberts 2008, pp. 214-215, Roberts et al. 
2009, pp. 1018-1019, Kienlin 2010, pp. 9-10, 80-84). This is proposed to have begun during the Bronze Age, but really commenced with the beginning of iron metallurgy during the first millennium BC. However, the ideas emphasising the significance of copper per se present a possibility that it was not the practical usefulness - in the modern or western sense - that made copper alluring, but rather its special properties, like colour, gloss, malleability, castability, plastic shape of copper nuggets and so forth (see Herva et al. 2012, 2014, Nordqvist and Herva 2013 for discussion). Accepting these premises, also the discrepant or ambiguous nature of the early copper finds from the north - mostly small bits and pieces of metal with no apparent function - becomes understandable; it was the copper itself and the qualities it (apparently) possessed that were important. In this respect the 'cultural meaning' of metal during the Neolithic is no less than later on when it was used in the production of 'functional' artefacts.

The Suomussalmi copper adze can also be understood against this background. Although it can be identified as a functional artefact - an adze - by the shape and it was also probably hard enough to be used as a tool, the absence of use-wear or even more substantial damage on its blade speak against such interpretation. On the contrary, the early metal items, just like Stone Age exotica, are often directly connected with the construction of social relationships. But as there is not an axiomatic connection between the early metals and technological functionality, there is neither an a priori link between them and the expression of social status (see e.g. Ottaway and Roberts 2008, p. 214, Thornton and Roberts 2009, p. 182, Kienlin 2010, p. 83). Accordingly, the Suomussalmi copper adze may not only have brought social value to its possessor, but also displayed or embodied the physical attributes and cognitive values related to the raw material in itself.

Some of the ideas presented above are, admittedly, in disagreement with the old narratives. As mentioned above, the western Bronze Age culture has traditionally been seen as the beginning of 'proper metal culture' in Finland (Salo 1981, p. 33, Edgren 1992, p. 70) and in general to represent the beginning of more 'civilised' or 'advanced' phase in the Finnish prehistory (see e.g. Lavento 2003, pp. 280-284 for examples), whereas the eastern culture of inland has, in many respects, acted just as its archaic backcloth. Still, there is no getting away from the fact that the first contacts with metal in the east predate the ones of the western Bronze Age culture by several millennia. Furthermore, the western emphasis largely neglects the fact that the eastern Bronze Age exhibits older, undisputed and more numerous signs of local metallurgy (see e.g. Huurre 1982, p. 28, 1986b, p. 57, Lavento 2001, pp. 124-126), although metal artefact finds are fewer. This tendency may be 
seen as a fitting example of the position the narrator has in the construction of the prehistoric narrative, highlighted in the introduction. The strong orientation towards the west is not a coincidence or only reflecting the 'real' prehistoric situation, but has a lot to do with scientific outlook, research history, political situation and personal attitudes of researchers during the second half of the 20th century (see also Nordqvist and Herva 2013, p. 419).

Secondly, the approach adopted here differs from the previous grand narratives in giving agency also to objects and immaterial things, in abandoning the purely techno-economical approach towards the prehistory and discarding the intrinsically rudimentary nature of the Neolithic in the research area. Especially the latter view has placed the Neolithic populations of north-eastern Europe in less-capable position in contrast to the 'real' Neolithic cultures of more southern regions. This has been one major factor which has hindered accepting certain cultural features, like the manipulation of native copper, to the prevailing scheme of the Stone Age. In traditional view such things, quite simply, do not fit within the framework: in this perspective it is not possible - or acceptable - that Stone Age societies in the north would have been familiar with features or concepts like metal or cultivation ${ }^{6}$, as these belong only to later and culturally (or cultural evolutionarily) 'more advanced' periods. However, if we accept the new, more nuanced and multilocal view of the Neolithic (e.g. Jordan and Zvelebil 2009, Jones et al. 2011, Thomas 2015), many traditionally unsuitable things can be incorporated into the grand narrative of the Stone Age in north-eastern Europe as an alternative scenario of how things might have happened. 


\section{References}

Alenius, T., Mökkönen, T. and Lahelma, A., 2013. Early farming in the northern Boreal Zone: reassessing the history of land use in southeastern Finland through high-resolution pollen analysis. Geoarchaeology, 28 (1), 1-24.

Björkman, T., 1961. Kertomus Polvijärven pitäjän Solan kylän Suovaaran kivikautisen asuinpaikan kaivauksesta v. 1960. Unpublished research report. Helsinki: National Board of Antiquities.

Boivin, N., 2004. From veneration to exploitation: human engagement with the mineral world. In: $\mathrm{N}$. Boivin and M. Owoc, eds. Soils, stones and symbols: cultural perceptions of the mineral world. London: University College of London Press, 1-29.

Chernyavskiy, A.V., Voloshin, A.V., Borisova, V.V., Borisov, A.E. and Pakhomovskiy Ya.A., 2010. Samorodnye Cu i Ag v effuzivakh Imandra-Varzugi. In: Yu.L. Voytekhovskiy, ed. Geologiya i poleznye iskopaemye Kolskogo poluostrova: Trudy VII Vserossiyskoy Fersmanovskoy nauchnoy sessii posvyashchennoy 80-letiyu Kolskogo nauchnogo tsentra RAN (2-5 maya 2010 g.) i Oblastnoy konferentsii posvyashchennoy 75-letiyu istoriko-kraevedcheskogo muzeya g. Kirovska (22-23 aprelya 2010 g.). Apatity-Kirovsk: izd-vo K\&M, 106-109.

Chernykh, E.N., 1992. Ancient metallurgy in the USSR: The Early Metal Age. Cambridge: Cambridge University Press.

Clark, C.P., and Martin, S.R., 2005. A risky business: Late Woodland copper mining on Lake Superior. In: P. Topping and M. Lynott, eds. The cultural landscape of prehistoric mines. Oxford: Oxbow Books, 110-122.

Coghlan, H.H., 1962. A note upon native copper: its occurrence and properties. Proceedings of the Prehistoric Society, 28, 58-67.

Coghlan, H.H., 1975. Notes on the Prehistoric Metallurgy of Copper and Bronze in the Old World. 2nd ed. Oxford: Oxford University Press.

Davies, P. and Robb, J., 2004. Scratches in the earth: The underworld as a theme in British prehistory, with particular reference to the Neolithic and Earlier Bronze Age. Landscape Research, 29 (2), 141-151.

Edgren, T., 1992. Den förhistoriska tiden. In: M. Norrbäck, ed. Finlands historia 1. Espoo: Schildts, 9-270.

Franklin, U.M., Badone, E., Gotthardt, R. and Yorga, B., 1981. An examination of prehistoric copper technology and copper sources in Western Arctic and Subarctic North America (National Museum of Man, Mercury series). Ottawa: National Museums of Canada.

Gaydarska, B. and Chapman, J., 2008. The aesthetics of colour and brilliance - or why were prehistoric persons interest in rocks, minerals, clays and pigments. In: R. Kostov, B. Gaydarska and M. Gurova, eds. Geoarchaeology and Archaeomineralogy: Proceedings of the International Conference, 29.-30. October 2008. Sofia: St. Ivan Rilski, 63-66. 
Grigoriev, S., 2015. Metallurgical production in northern Eurasia in the Bronze Age. Oxford: Archaeopress.

Gurina, N.N., 1951. Poseleniya epokhi neolita i rannego metalla na severom poberezhe Onezhskogo ozera. In: M.E. Foss, ed. Poseleniya epokhi neolita i rannego metalla na Severe evropeyskoy chasti SSSR. Moskva-Leningrad: Akademiya nauk SSSR, 77-142.

Gurina, N.N., 1961. Drevnjaja istorija severo-zapada evropejskoj časti SSSR. Materialy i issledovanija po arheologii SSSR 87. Moskva, Leningrad: Akademii nauk SSSR.

Herva, V.-P., Ikäheimo, J., Kuusela, J.-M. and Nordqvist K., 2012. Close encounters of the copper kind. In: R. Berge, M.E. Jasinski and K. Sognnes, eds. N-TAG TEN, the Proceedings of the 10th Nordic TAG conference at Stiklestad, Norway 2009. Oxford: Archaeopress, 109-115.

Herva, V.P., Nordqvist, K., Lahelma, A. and Ikäheimo, J., 2014. Material engagements, cultivation of perception and the emergence of the Neolithic world. Norwegian Archaeological Review, 47 (2), 141-160.

Hölttä, P. and Rosenberg, R., 1987. Determination of the elemental composition of copper and bronze objects by neutron activation analysis. Journal of Radioanalytical and Nuclear Chemistry, 114 (2), 403-408.

Huggert, A., 1996. Early copper finds in northern Fennoscandia. Current Swedish Archaeology, 4, 69-82.

Huurre, M., 1979. 9000 vuotta Suomen esihistoriaa. Helsinki: Otava.

Huurre, M., 1982. Suomussalmen varhaista metallikautta. Suomen Museo, 88 (1981), 11-30.

Huurre, M., 1983. Pohjois-Pohjanmaan ja Lapin esihistoria. Pohjois-Pohjanmaan ja Lapin historia I. Oulu: Pohjois-Pohjanmaan maakuntaliiton ja Lapin maakuntaliiton yhteinen historiatoimikunta.

Huurre, M., 1986a. Esihistoria. Kainuun historia I. Kajaani: Kainuun Sanomain Kirjapaino Oy.

Huurre, M., 1986b. The eastern contacts of northern Fennoscandia in the Bronze Age. Fennoscandia archaeologica, III, 51-58.

Huurre, M., 1992. Leipä luonnosta - Suomussalmen historian kymmenen vuosituhatta. Helsinki: Otava.

Huurre, M., 1998. Kivikauden Suomi. Helsinki: Otava.

Huurre, M., 1999. Adze from Suikkila in Turku, south-west Finland. In: M. Huurre, ed. Dig It All: Papers Dedicated to Ari Siiriäinen. Helsinki: The Finnish Antiquarian Society and 7he Archaeological Society of Finland, 181-184.

Hyttinen, M., Oikarinen, T. and Rajala, A., 2000. Suomussalmi Kukkosaari. Tutkimuskertomus kesällä 1999 suoritetusta arkeologisesta kaivauksesta (SKS-99). Unpublished research report. Helsinki: National Board of Antiquities. 
Hyttinen, M., Oikarinen, T. and Rajala, A., 2001. Suomussalmi Kukkosaari. Tutkimuskertomus kesällä 2000 suoritetusta arkeologisesta kaivauksesta (SKS-00). Unpublished research report. Helsinki: National Board of Antiquities.

Hytönen, K., 1999. Suomen mineraalit. Helsinki: Geologian tutkimuskeskus.

Hölttä, P. and Rosenberg, R., 1987. Determination of the elemental composition of copper and bronze objects by neutron activation analysis. Journal of Radioanalytical and Nuclear Chemistry, $114(2), 403-408$.

Ikäheimo, J., 2011. Arkeologisten löytöjen alkuaineanalytiikka Suomessa. Suomen Museo, 117, 3149.

Ikäheimo, J., 2014. Suomen kivikautisten kuparilöytöjen metallin alkuperästä. Muinaistutkija, 2/2014, 11-26.

Ikäheimo, J. and Pääkkönen, M., 2009. Kierikin kupariveitsi - uusimpia tutkimustuloksia. In: J. Ikäheimo and S. Lipponen, eds. Ei kiveäkään kääntämättä. Juhlakirja Pentti Koivuselle. Oulu, 165177.

Johnston, R., 2008. Copper mining and the transformation of environmental knowledge in Bronze Age Britain. Journal of Social Archaeology, 8 (2), 190-213.

Jones, M., Hunt, H., Lightfoot, E., Lister, D., Liu, X. and Motuzaite-Matuzeviciute, G., 2011. Food globalization in prehistory. World Archaeology, 43 (4), 665-675.

Jordan, P. and Zvelebil, M., 2009. Ex oriente lux: the prehistory of hunter-gatherer ceramic dispersals. In: P. Jordan and M. Zvelebil, eds. Ceramics before farming: the dispersal of pottery among prehistoric Eurasian hunter-gatherers. Walnut Creek (CA): Left Coast Press, 33-89.

Kienlin, T.L., 2010. Traditions and transformations: approaches to Eneolithic (Copper Age) and Bronze Age metalworking and society in Eastern and Central Europe and the Carpathian Basin. British Archaeological Reports International Series 2184. Oxford: Archaeopress.

Kinnunen, M., 2010. Kuparin vai kunnian tähden. Herajoen kupariruukin historia. Jyväskylä: Kopijyvä.

Kosmenko, M.G. and Kochkurkina, S.I., 1996. Arkheologiya Karelii. Petrozavodsk: Karelskiy nauchnyi tsentr RAN.

Kriiska, A., 2009. The beginning of farming in the Eastern Baltic. In: P.M. Dolukhanov, G.R. Sarson and A. Shukurov, eds. The East European Plain on the eve of agriculture. Oxford: British Archaeological Reports 1964, 159-179.

Kuleff, I. and Pernicka, E., 1995. Instrumental neutron activation analysis of native copper: some methodological considerations. Journal of Radioanalytical and Nuclear Chemistry, 191 (1), 145161.

Lahtinen, M. and Rowley-Conwy, P., 2013. Early farming in Finland: was there cultivation before the Iron Age (500 BC)? European Journal of Archaeology, 16 (4), 660-684. 
Laitakari, A., 1967. Suomen mineraalien hakemisto. Bulletin de la Commission Géologique de Finlande 230. Otaniemi: Geologinen tutkimuslaitos.

Lavento, M., 2001. Textile ceramics in Finland and on the Karelian Isthmus: nine variations and fugue on a theme of C. F. Meinander. Helsinki: Finnish Antiquarian Society.

Lavento, M., 2003. Viipurin läänin pronssikausi ja varhaismetallikausi. In: M. Saarnisto, ed. Karjalan synty. Viipurin läänin historia 1. Sine loco, Karjalaisen Kulttuurin Edistämissäätiö, Karjalan Kirjapaino Oy, 245-290.

Luoto, J., 2012. Kivikautisesta maanviljelyksestä. Suomen Museo, 118, 106-116.

Maddin, R., Stech Wheeler, T. and Muhly, J.D., 1980. Distinguishing artifacts made of native copper. Journal of Archaeological Science Volume, 7 (3), 211-225.

Martin, S.R., 1999. Wonderful power: the story of ancient copper working in the Lake Superior Basin. Detroit (MI): Wayne State University Press.

Matiskainen, H., 1979. Suomusalmen Kukkosaari. Kaivaustutkimukset 14.7.-14.8.1979. Unpublished excavation report. Helsinki: National Board of Antiquities.

Mauk, J.L. and Hancock, R.G.V., 1998. Trace element geochemistry of native copper from the White Pine Mine, Michigan (USA): implications for sourcing artefacts. Archaeometry, 40 (1), 97107.

Meinander, C.F., 1962. Kertomus intendentti C.F. Meinanderin kaivauksista Polvijärven pitäjän Solan kylässä sijaitsevalla Suovaaran kivikautisella asuinpaikalla 27.-29.7.1961. Unpublished research report. Helsinki: National Board of Antiquities.

Melezhik, V.A., 2012. The Imandra/Varzuga Greenstone Belt. In: V. Melezhik, A.R. Prave, E.J. Hanski, A.E. Fallick, A. Lepland, L.R. Kump and H. Strauss, eds. Reading the archive of earth's oxygenation. Volume 1: The Palaeoproterozoic of Fennoscandia as context for the Fennoscandian Arctic Russia - Drilling Early Earth Project. Heidelberg: Springer, 249-287.

Mökkönen, T., 2010. Kivikautinen maanviljely Suomessa. Suomen Museo, 116, 5-38.

Mökkönen, T., 2011. Kivikautisen maanviljelyn olemassaolo on todistettavissa siitepölyanalyysillä. Suomen Museo, 117, 139-142.

Mökkönen, T. 2012. Kivikautisesta maanviljelyksestä - vastine Jukka Luodolle. Suomen Museo, $118,117-122$.

Mökkönen, T. and T. Alenius, 2012. Stone Age cereal cultivation in Finland: cerealia-type pollens in old and new high-resolution pollen analyses. 18th annual meeting of the European Association of Archaeologists, Abstracts. Helsinki: European Association of Archaeologists, 287.

Nordqvist, K. 2013. Of the periodization of Eneolithic-Bronze Age in north-east Europe/Периодизация Неолита - Бронзового века в Северо-Восточной Европе // Проблемы периодизации и хронологии в археологии эпохи раннего металла Восточной Европы (В.С. Бочкарев \& А.И. Мурашкин). СПб. 
Nordqvist, K., Herva, V.-P., Ikäheimo J. and Lahelma, A., 2012. Early copper use in Neolithic northeastern Europe: an overview. Estonian Journal of Archaeology, 16 (1), 3-25.

Nordqvist, K. and Herva V.-P., 2013. Early copper use and Neolithization in north-eastern Europe (c. 5500-1800 BC). European Journal of Archaeology, 16 (3), 401-432.

Núñez, M. and Okkonen, J., 2005. Humanizing of north Ostrobothnian landscape during the 4th and 3rd millennia BC. Journal of Nordic Archaeological Science, 15, 25-38.

Okkonen, J., 2003. Jättiläisen hautoja ja hirveitä kiviröykkiöitä: Pohjanmaan muinaisten kivirakennelmien arkeologiaa. Acta Universitatis Ouluensis. Series B, Humaniora. Oulu: Oulun yliopisto.

Ottaway, B.S. and Roberts, B., 2008. The emergence of metalworking. In: A. Jones, ed. Prehistoric Europe: Theory and Practice. Chichester: Wiley-Blackwell, 193-225.

Pesonen, P., 2004. Neolithic pots and ceramic chronology: AMS-Datings of Middle and Late Neolithic ceramics in Finland In: P. Uino, ed. Fenno-ugri et slavi 2002: Dating and chronology. Museoviraston arkeologian osaston julkaisuja 10. Helsinki: Museovirasto, 87-97.

Rapp, G., 2009. Archaeomineralogy. 2nd ed. London and Berlin: Springer.

Roberts, B.W., Thornton, C.P. and Pigott, V.C., 2009. Development of metallurgy in Eurasia. Antiquity, 83, 1012-22.

Saipio, J., 2011. Lapinrauniotradition kehitys ajoitusten valossa. Muinaistutkija, 4/2011, 19-35.

Salo, U., 1981. Satakunnan pronssikausi. Satakunnan historia 1.2. Rauma: Satakunnan maakuntaliitto.

Salo, U., 1984. Pronssikausi ja rautakauden alku. In: Y. Blomstedt et al., eds. Suomen historia 1. Espoo: Weilin+Göös, 98-249.

Saltikoff, B., 1997. Malmiesiintymäkortisto. Helsinki: Geologian tutkimuskeskus.

Sarvas, P., 1969. Esihistoriallinen katsaus. In: A.V.A. Könönen and H. Kirkinen, eds. Pohjois-Karjalan historia I. Joensuu: Karjalaisen kulttuurin edistämissäätiö, 9-183.

Schanche, K., 1989. Nye funn fra yngre steinalder i Varanger. Viking, 52, 53-71.

Schroeder, D.L. and Ruhl, K.C., 1968. Metallurgical characteristics of North American pre-historic copper work. American Antiquity, 33 (2), 162-169.

Simola, H., 2011. Kivikautista maanviljelyä ei voi todistaa siitepölyanalyysillä. Suomen Museo, 117, 137-138.

Stenbäck, N., 2003. Människorna vid havet. Platser och keramik på Ålandsöarna perioden 35002000 f.Kr. Stockholm Studies in Archaeology 28. Institutionen för arkeologi, Stockholm universitet. Taavitsainen, J.-P., 1982. A copper ring from Suovaara in Polvijärvi, Northern Karelia. Fennoscandia antiqua I, 41-49. 
Taavitsainen, J.-P., 2003. Lapinraunioiden kronologis-funktionaalisten kysymysten hahmottelua uusia AMS-ajoituksia Keski-Suomen palaneesta luusta. Muinaistutkija, 1/2003, 2-23.

Tallgren, A.M., 1911. Die Kupfer- und Bronzezeit in Nord- und Ostrussland. I. Die Kupfer- und Bronzezeit in Nordwestrussland. Die altere Metallzeit in Ostrussland. Suomen Muinaismuistoyhdistyksen Aikakauskirja 25:1. Helsinki: Suomen muinaismuistoyhdistys.

Tarasov, A.Yu., 2004. Eneoliticheskaya industriya kamennykh makroorudiy na territorii Karelii, $\mathrm{k}$ voprosu o spetsializatsii v proizvodstve. In: A.V. Chernetsov, ed. Evraziya: etnokulturnoe vzaimodeystvie i istoricheski sudby. Moskva: RGGU, 9-47.

Tarasov, A.Yu., 2008. Eneoliticheskaya industriya kamennykh markoorudiy Karelii v ryadu evropeyskikh industriy pozdnego kamennogo veka. In: G.A. Khlopachev, ed. Khronologiya, periodizatsiya i kross-kulturalnye svyazy v kamennom veke. Sankt-Peterburg: Nauka, 190-201.

Thomas, J., 2015. What do we mean by 'Neolithic societies'? In: C. Fowler, J. Harding and D. Hofman, eds. The Oxford Handbook of Neolithic Europe. Oxford: Oxford University Press, 10731092.

Tilley, C., 2007. The Neolithic sensory revolution: monumentality and the experience of landscape. In: A. Whittle and V. Cummings, eds. Going over: the Mesolithic-Neolithic transition in north-west Europe. London: British Academy, 329-345.

Tylecote, R.F., 1987. The Early History of Metallurgy in Europe. London: Longman.

Vesajoki, H., 2000. Herajoen kupariruukin nousu ja unohdus. In: L. Lovén and H. Rainio, eds. Kolin perintö: kaskisavusta kansallismaisemaan. Helsinki: Metsäntutkimuslaitos \& Geologian tutkimuskeskus, 136-137.

Västi, K., 2010. FINCOPPER - A Public Database on Copper Deposits in Finland. Geological Survey of Finland. Version 1.1.

Watkins, T., 2013. The Neolithic in transition - how to complete a paradigm shift? Levant, 45 (2), 149-158.

Wayman, M.L., 1985a. Native copper: humanity's introduction to metallurgy? Part 1: occurrence, formation and prehistoric mining. CIM Bulletin, 78 (No. 880), 67-69.

Wayman, M.L., 1985b. Native copper: humanity's introduction to metallurgy? Part II: Metallurgical Characteristics and Utilization. CIM Bulletin, 78 (No. 881), 75-77.

Wayman, M.L. and Duke, M.J.M., 1999. The effects of melting on native copper, In: A. Hauptmann, E. Pernicka, T. Rehren and U. Yalcin, eds. The Beginnings of Metallurgy, Der Anschnitt Beheft 9. Bochum, Bergbau Museum, 55-63.

Wilson, G.C., Pavlish, L.A., Ding, G.-J. and Farquhar, R.M., 1997. Textural and in situ analytical constraints on the provenance of smelted and native archaeological copper in the Great Lakes region of Eastern North America. Nuclear Instruments and Methods in Physics Research Section B: Beam Interactions with Materials and Atoms, 123 (1-4), 498-503. 
Ylimaunu, T. and Costopoulos, A., 1998. Oliko kivikausi jo varhaismetallikautta? Hiidenkivi, 1/98, 18-20.

Zhulnikov, A.M., 1999. Eneolit Karelii. Petrozavodsk: Rossiyskaya akademiya nauk.

Zhuravlev, A.P., 1991. Pegrema (poseleniya epokhi eneolita). Petrozavodsk: Karelskiy nauchnyi tsentr AN SSSR.

Zhuravlev, A.P., Devyatova, E.I. and Vrublevskaya E.L., 1981. Mednye izdeliya stoyanki Zalavruga IV. Sovetskaya arkheologiya, 4/1981, 247-250.

Zhuravlev, A.P., Chistyakova, E.L. and Zhulnikov, A.M., 1991. Novye dannye po obrabotki samorodnoy medi v eneolite Karelii. Sovetskaya arkheologiya, 1/1991, 167-172.

Zvelebil, M., 2006. Mobility, contact, and exchange in the Baltic Sea basin 6000-2000 BC. Journal of Anthropological Archaeology, 25 (2), 178-192. 


\section{Table}

Table 1. The results of three elemental analysis performed on the Suomussalmi copper adze (KM 20850).

\begin{tabular}{|c|c|c|c|}
\hline & $A E S^{1)}$ & INAA $^{2)}$ & EPMA $^{3)}$ \\
\hline & Unit & $\mathrm{ppm}$ & $\%$ \\
\hline $\mathrm{Cu}$ & & $100^{4)}$ & 99.687 \\
\hline $\mathrm{P}$ & $<0.2$ & - & - \\
\hline $\mathrm{Bi}$ & $<0.001$ & - & - \\
\hline $\mathrm{Fe}$ & 0.005 & - & - \\
\hline $\mathrm{Ni}$ & 0.012 & $<18$ & - \\
\hline $\mathrm{Pb}$ & 0.009 & - & - \\
\hline $\mathrm{Zn}$ & $<0.01$ & $<17$ & - \\
\hline Sn & $<0.003$ & $<0.2^{4)}$ & - \\
\hline $\mathrm{Al}$ & $<0.002$ & $<12$ & - \\
\hline $\mathrm{Mn}$ & 0.003 & 7.14 & - \\
\hline $\mathrm{Ag}$ & $0.005-0.007$ & 225 & $<0.03$ \\
\hline Si & 0.005 & - & - \\
\hline As & $<0.07$ & 3.61 & - \\
\hline $\mathrm{Sb}$ & $<0.01$ & 10.4 & - \\
\hline $\mathrm{Mg}$ & $<0.003$ & $<2350$ & - \\
\hline V & - & 1.29 & - \\
\hline Co & - & 8.24 & - \\
\hline W & - & 8.56 & - \\
\hline Ir & - & .028 & - \\
\hline $\mathrm{Au}$ & - & .067 & - \\
\hline$S$ & - & - & 0.198 \\
\hline
\end{tabular}




\section{Captions}

Fig. 1. The Suomussalmi copper adze. Photos: K. Nordqvist, montage \& editing: J. Ikäheimo.

Fig. 2. The location of Suomussalmi Kukkosaari (1) and other locations mentioned in the article: 2 - Zalavruga IV, 3 - Varris, 4 - Polvijärvi Sola, 5 - Oulu Kierikki Kuuselankangas, 6 - Karlebotnbakken, 7 - Rääkkylä Vihi 1, 8 - Jomala Jettböle. Dots mark the locations of other Stone Age settlement sites with native copper finds.

Fig. 3. A detailed map of Kukkosaari's location and the Stone Age and Bronze Age sites in its vicinity. Map by K. Nordqvist.

Fig. 4. A view from the southern part of the Kukkosaari esker towards the northern part. The adze was found from the heavily eroded southern part of the island 'on a sandy shore between the rocks'. Photo: A. Rajala/Laboratory of Archaeology, University of Oulu [IX-48-2-3].

Fig 5. a) microphotograph of the non-etched surface showing tiny blebs resulting from casting; b) microphotograph of the etched surface showing the heterogeneous crystal structure of the copper metal.

Fig 6. Two cast copper implements that vaguely resemble the Suomussalmi copper adze: a copper adze preform from Varris in Sweden (left) and a small copper adze from Zalavruga IV dwelling-site in Russian Karelia (right). Montage: K. Nordqvist.

\footnotetext{
${ }^{1}$ In this paper terms Neolithic Stone Age (c. 5500-1800 BC) and Bronze Age (c. 1800-500 BC) are used according to Finnish periodisation. In research literature also terms Early Metal Period or Early Metal Age are frequently encountered; in Karelia (Russia) this period includes the Eneolithic (c. 3500-1800 BC) and the Bronze Age (c. 1800-800 BC) but in Finland the Bronze Age (c. 1800/1500-500 BC) and the Early Iron Age (c. 500 BC-AD 300/400) (see Nordqvist 2013). All dates given in this paper are calibrated, unless otherwise noted.

${ }^{2}$ The adze has been displayed in the permanent prehistory exhibition of the National Museum of Finland, which is at the moment undergoing a complete renovation. It was documented in November 2012 with Breuckmann SmartScan 3D -artefact scanner equipped with FOV-5.0-M-125 lenses providing ca. $40 \mu \mathrm{m} x, y$-resolution. The resulting mesh consists of $c .3 .14$ million vertices and 6.27 million triangles.

${ }^{3}$ The idea of copying metal artefacts in stone during the Late Neolithic is not overtly rare or new; similarly, battle axes of the Corded Ware culture and Late Neolithic flint sickles of the Kiukainen culture have been interpreted as imitations of metal artefacts in stone (e.g. Salo 1981, pp. 34-35; 1984, p. 106; Huurre 1998, p. 325).

${ }^{4}$ The perforated copper sheets found in Jettböle have been connected to the influence of Neolithic Swedish Pitted Ware (Salo 1984, p. 107; Edgren 1992, p. 70) in the Åland Islands and consequently seen as an indication that the early knowledge about copper spread, at least to some extent, also from the west (Salo 1981, p. 34, 1984, p. 106; also Huggert 1996, p. 69). However, introductory elemental analysis conducted on this material with the pXRF showed that these pieces are made of bronze (see Ikäheimo 2014, p. 16, Table 3) and therefore more likely associated with the Bronze Age activities also evident at the site (see Stenbäck 2003, pp. 182-184).

${ }^{5}$ A sample from charred crust on a shard of Late Neolithic asbestos-tempered pottery of Pöljä type from the Kukkosaari site has been AMS-dated (Pesonen 2004), and gave the result c. 3400-2800 cal BC (4390 \pm 100 BP [Hela145]). In addition, a more recent date was obtained from a stone cairn/possible burial located on the Kukkosaari Island (2090 \pm 70 BP [Beta-149530], Hyttinen et al. 2001). Neither of these dates can be directly connected with the adze.

${ }^{6}$ See, e.g., the debate on the pollen evidence of early (i.e. late 6th-4th millennium BC) agriculture in north-eastern Europe (e.g. Kriiska 2009, Mökkönen 2010, 2011, 2012, Mökkönen and Alenius 2012, Simola 2011, Luoto 2012, Alenius et al. 2013, Lahtinen and Rowley-Conwy 2013).
} 

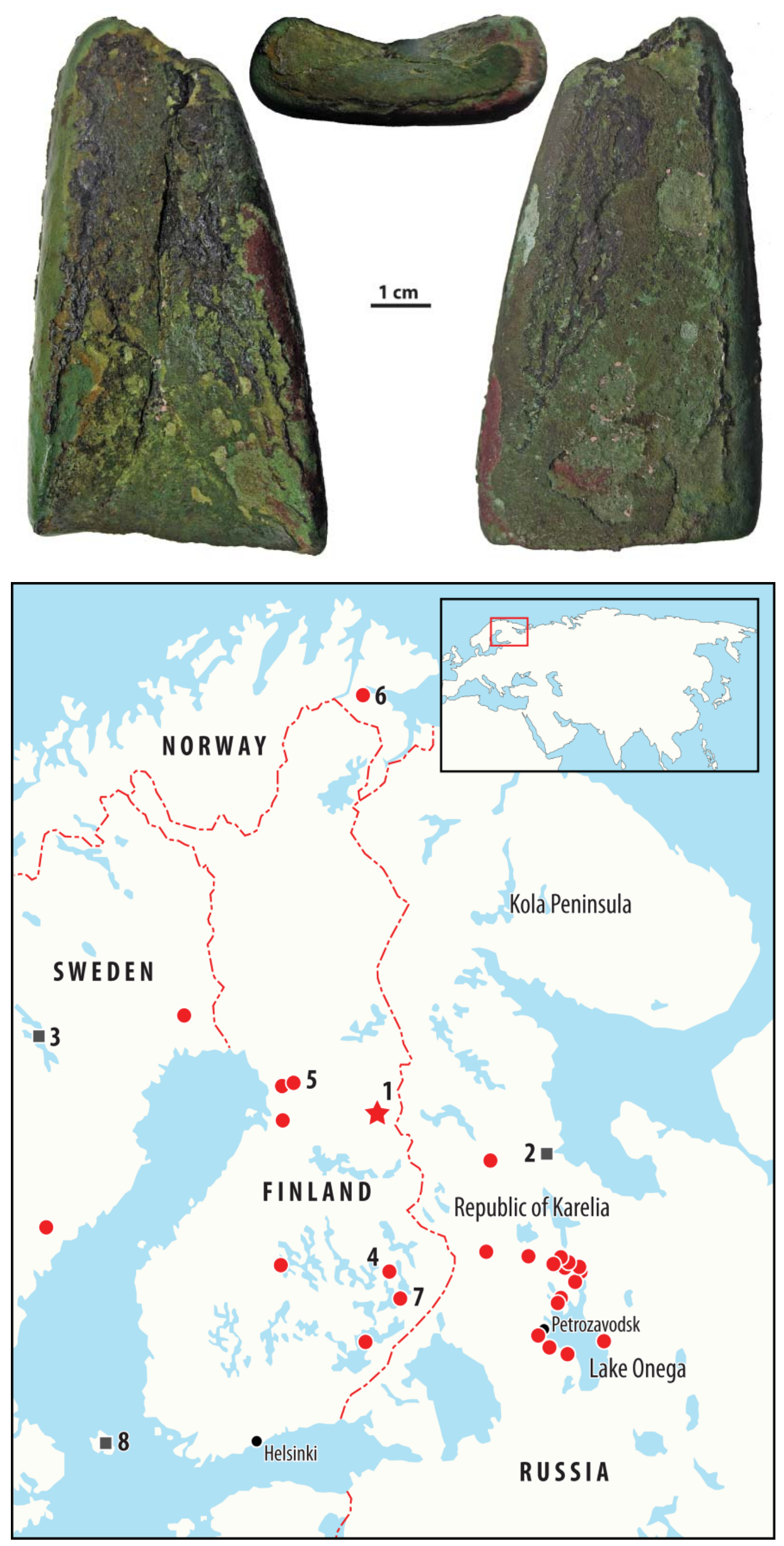

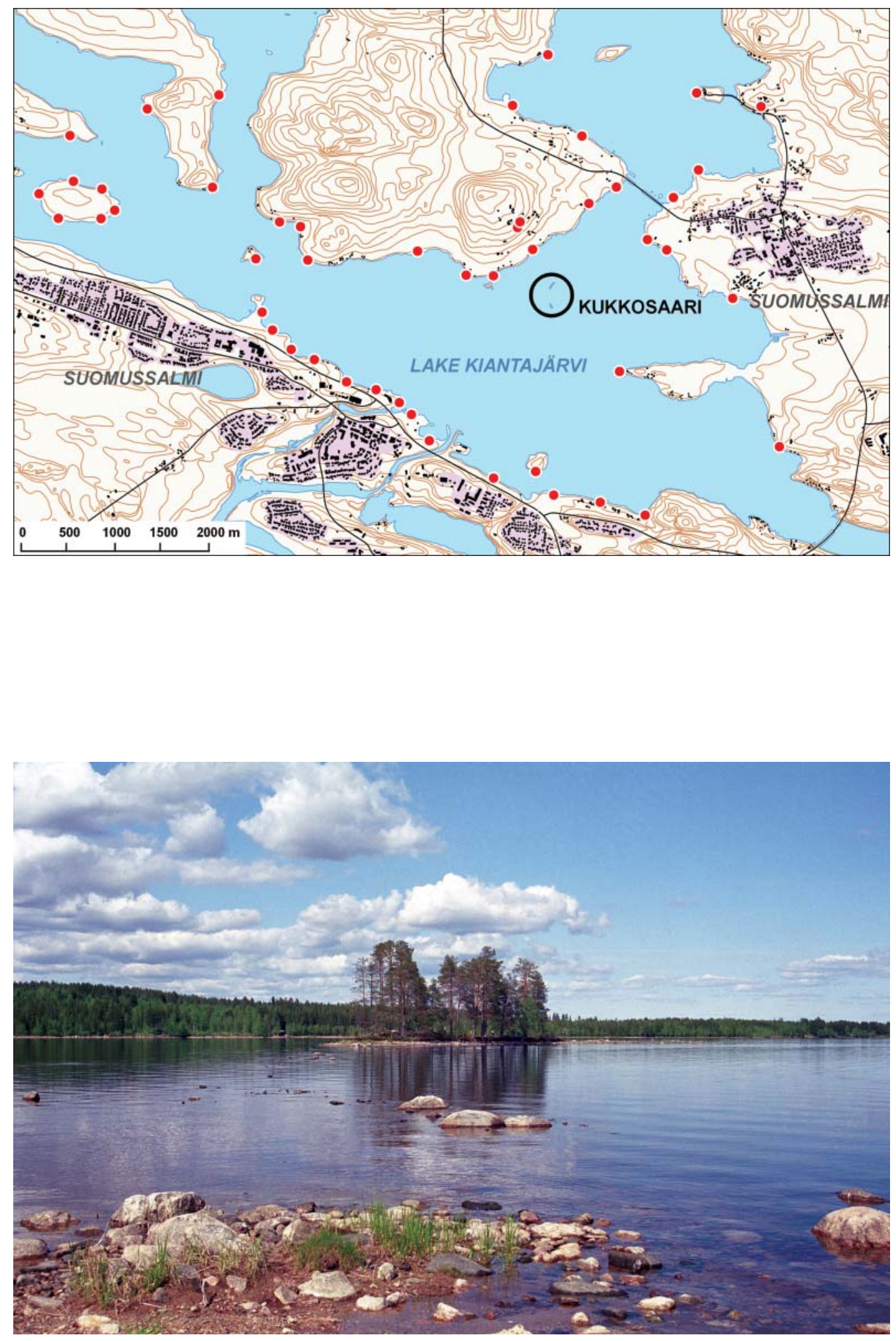

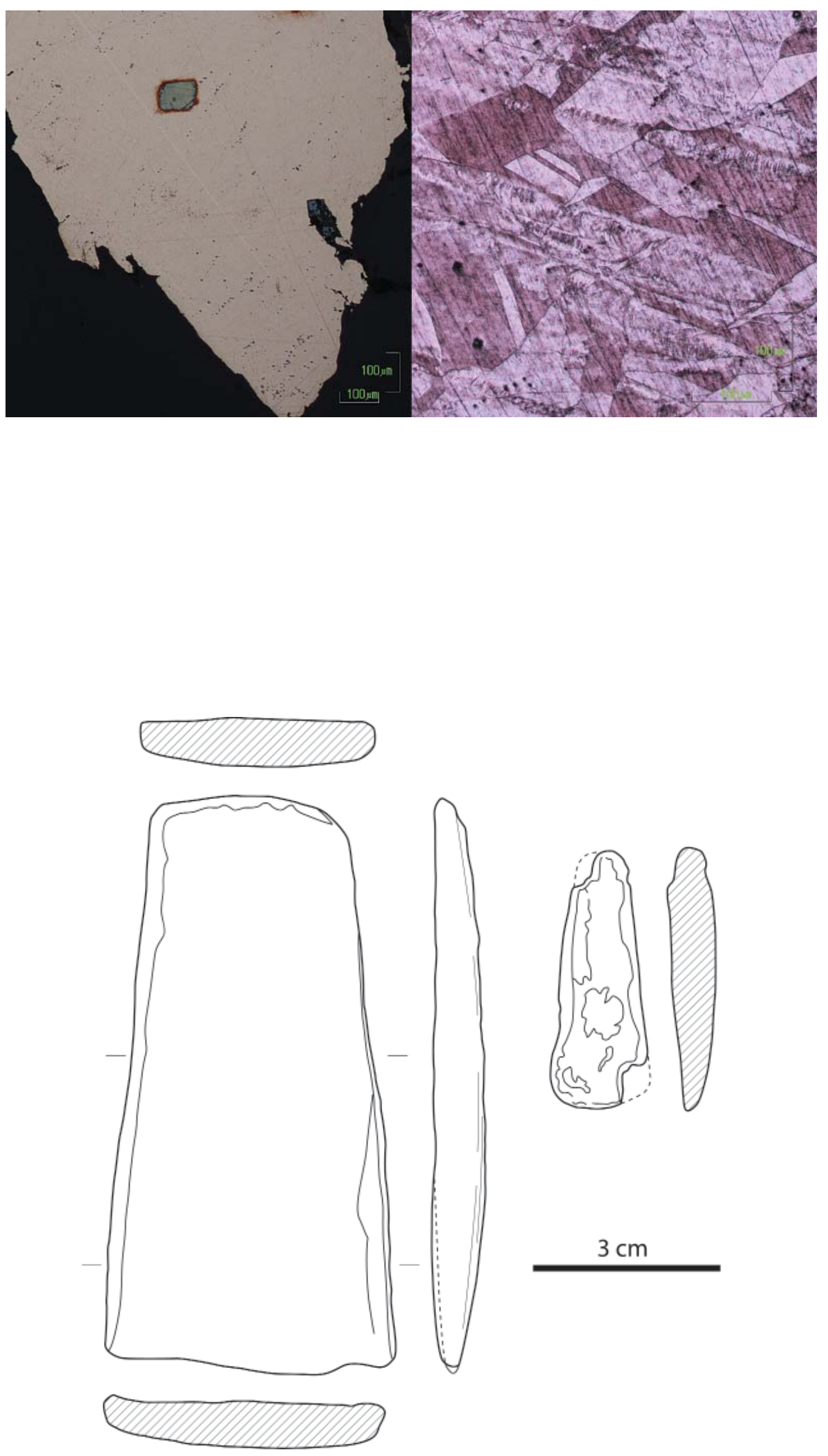